\title{
Problematic of Tourism in Adıyaman: Multidimensional Barriers with a Community Perspective
}

\author{
Caner Çalışkan*, Hülya Yeşilyurt
}

\section{ABSTRACT}

\author{
Keywords: \\ Tourism, \\ Community, \\ Socio-Culture, \\ Socio-Economy, \\ Geography, \\ Adryaman
}

Article History:

Submitted:09.03.2020

Accepted: 18.07 .2020

\begin{abstract}
Tourism success is an important parameter of regional development. The way a society perceives tourism and existing issues and the rate of participation in political decisions are also important factors, particularly for developing regions. In this sense, the perspective of the locals provides a significant clue for researchers and policy makers. In this study, the tourism development of Adryaman, one of the potential tourism destination of Turkey, has been analyzed through a societal perspective. 187 people have been selected through convenience sampling method under the scope of the study and they have been posed open-ended questions. The acquired data have been categorized under three sections as sociocultural, socio-economic and geographic barriers. As a result of the study, the most significant barriers for tourism are defined as the local administration, investment, transport and promotion
\end{abstract}

\section{Doi: https://doi.org/10.31822/jomat.749304}

\section{Introduction}

The interaction between social structure and tourism development is important in any region. However, this interaction can turn into a social issue due to the complicated structure and mechanism of tourism (Kim, Chen and Jang, 2006; Lee and Chang, 2008). As such, tourism becomes the multi-dimensional outcome of relations formed within a community or with other communities (Avcıkurt, 2009). In a similar description, tourism is a system that is formed by local dynamics in economic and socio-cultural terms and reflects local characteristics (Rızaoğlu, 2003; Kim, Uysal and Sirgy, 2013). Therefore, community is the most important stakeholder of tourism (Choi and Sirakaya, 2005; Homsud and Promsaard, 2015). On the other hand, existing values are highly effective in a society's perception of tourism (Matthews and Richter, 1991; Liu, 2006; Eshliki and Kaboudi, 2012). At this point, social structure, which is the sum of existing values, becomes a factor that defines the level of social awareness, trust and partnership (Gulati, 1995). In other words, in a community's approach towards tourism
(Stylidis, et al. 2014; Lee, 2013), the way tourism has positioned itself within social structure (García, Vázquez and Macías, 2015), the way it penetrates social life (Tucker and Boonabaana, 2012) and benefit-cost ratio (Perdue, Long and Allen, 1990; Yoon, Gursoy and Chen, 2001; Gursoy, Jurowski and Uysal, 2002) are determinant factors.

As can be understood from the statements, the multiple and variable interaction between human and place (Giddens, 2013; Urry, 2015) is similar to the tourism and human interaction in that place (Bjeljac and Ćurčić, 2006). This interaction becomes even more distinctive particularly in developing places (Morton, 2003), because the effects of tourism-based transition in these areas penetrate all areas of social life from physical infrastructure to living standards (Kim, Uysal and Sirgy, 2013). From this point of view, the subject of research was handled on the basis of Adryaman. As a developing region, Adryaman failed to gain the anticipated tourism development momentum despite its potential and tourism has rather become a multi-dimensional issue (Yllmaz and

\footnotetext{
"Corresponding Author $\quad$ Research Paper

Caner Çalışkan: 1769

PhD. Research Assist., Adivaman University Faculty of Tourism, Email: hyesilyurt@ adivaman.edu.tr, Orcid Id: 0000-

Hülya Yeşilyurt: 0002-9991-2557
} 
Çalışkan, 2015). At this point, Franklin and Crang (2001) emphasize the need to interpret tourism in different aspects (environment, economy and socioculture) and from a social perspective. Therefore, in order to solve the dilemmas faced in tourismdevelopment phase in Adıyaman (Çalışkan and Dedeoğlu, 2018), the first thing to do is to understand the community (Reisinger and Turner, 2003). Understanding the community could also become a functional data source for long-term planning and implementation practises (Gursoy and Rutherford, 2004). At this point, the perception of the locals towards tourism within the social structure (Chandralal, 2010) can become a significant reference point in the development of tourism (Andereck and Vogt 2000). In this sense, the purpose of this current study is to analyse barriers of tourism development in Adiyaman through the local perspective and within the context of various dimensions.

\section{Literature}

\section{Regional Tourism Development}

Tourism is a strategic driver (Usta, 2009; Kim, Uysal and Sirgy, 2013) of regional development (Budeanu, 2005) and it is an important interaction factor that generates outputs in social and economic dimensions (Ahmad, 2013) and affects social life (Haley, Snaith and Miller, 2005). The actual expectation from tourism development is contribution to living standards in economic, sociocultural and environmental manner ( $\mathrm{McCool}$ and Martin, 1994). With this aspect, regional tourism development is a complicated issue involving social, political and economic aspects (Grandpré and Py, 2007) and the literature on the subject includes various studies addressing the issue from different angles and different disciplines (Dowling, 1993; Telfer, 2002; Romão, Guerreiro and Rodrigues, 2013; Liang and Chan, 2018). A majority of these studies are on the time-wise and spatial transitions of regions, their development policies, planning difficulties, marketing difficulties and strategy development (Henderson, 2006). A more detailed analysis of the subject indicates that the barriers of regional tourism development consist of several factors such as indifference, institutional weaknesses, lack of investment and insufficient participation in decision-making processes (Aref, 2010; Karakuş, 2019). According to Jansen (2003), the main barriers are the lack of investors acting on a voluntary basis, expectation of revenues in shortterm, ignoring population structure in planning, indefinite development limits geographically and resistance towards change. On the other hand,
James (1998) emphasizes that bureaucratic and politic factors are significant dilemmas, while Waligo, Clarke and Hawkins (2013) believe one of the greatest barrier is the fact that stakeholders are failing to provide sufficient contribution for tourism development. On this bases, Walmsley (2002) emphasize the need to have a strong communication between stakeholders. The actual problem in here is that tourism is generally considered from an economic perspective (Furmolly \& Kırkulak Uludağ, 2018). This approach, in a way, is actually ignoring the social aspects of tourism, which offers more than economic contribution in regional development. The reality is that community factor must be included in the process as an integral part of regional development strategy (Macbeth, Carson and Northcote, 2004). Therefore, it should be noted that the social, environmental and economic aspects of the issue should be equally treated (Hancock, 2001) and they need to be addressed through a social perspective.

\section{Community Perspective in Regional Tourism Development}

Social perspective is highly important in regional tourism development. The approaches of local people towards tourism can also provide clues about the development and transition capability of a region. According to Urry (2015), the main dimensions in tourism approach are economic, social and geographical factors. Accordingly, it is possible to say that the main factors affecting the perception of a community towards tourism are geography, socio-economy and socio-culture (Akama and Kieti, 2007; Çalışkan, 2015; Wu and Chen, 2015; Çalışkan and Dedeoğlu, 2018).

\section{- Geography}

Geography defines the quality of life (Knox and Pinch, 2014). According to Rentfrow, Jokela and Lamb (2015), interpretation of geography is important to understand and make sense of the connection between the place and lifecycle. Stoltman (1997) describes geography as a local's adaptation tool for change. Farole, Rodriguez-Pose and Storper (2011) associated a region's development potential with the interaction between human and geography, further to the socio-politic and economic factors. Furthermore, place-tourism interaction is another important issue (Harrill, 2004) and the perception of this interaction by the local community can vary depending on time, place and geography (García, Vázquez and Macías, 2015). It should be emphasized that geography is also a way of communication between regions (Giddens, 2013). 
This is no different when it comes to tourism. For instance, accessibility and distance are two important factors for the formation of a connection between a visitor and the visited area and these two factors are directly related to geography (Akdağ and Öter, 2011; Joo et.al., 2017). Hence, geography accommodates deep-rooted meanings for the formation of tourism perception.

- Socio-economy

Socio-economy is a multi-dimensional concept building bridges between different disciplines (Jakobsen, 2017) and it covers different overlapping subjects (Jiang et.al., 2016). When reviewed in terms of economy and community, it becomes clear that the concept is an important variable for tourism. Economy forms the basis of tourism and depending on human mobility, tourism creates new revenue items in different fields (Sanmargaraja and Wee, 2013), hence it becomes influential on a wide area (Akinboade and Braimoh, 2010). To be more precise, this has deeprooted effects on the social lives of individuals (Ghanian, Ghoochani and Crott, 2014), from new employment opportunities to income growth (Archer, Cooper and Ruhanen, 2005). Hence, the relation of tourism with socio-economy can turn into a significant parameter in terms of social perspective.

\section{- Socio-Culture}

Socio-culture is a phenomena that is reflected through several variables such as values, norms, beliefs, education, social stratification, profession, behavioural patterns and traditions (Mutsikiwa and Basera, 2012: 115). Therefore, the attitude that occurs within a socio-cultural structure is the starting point of regional development and transition (Larsen, 2008). And tourism is being shaped within this structure. According to Dinu (2018), tourism is a socio-cultural experience that help people to satisfy their needs to relax, travel, discover or socialise with other people (Dinu, 2018: 183). At this point, socio-culture also becomes a factor that illustrate the geography an individual is in (Robinson, 1999; Lin, Li and Hong, 2012) and can influence the social perspective in any given subject. As expressed by Doğan (2004), tourism is a social fact and the most important dynamics that influence the development process of tourism are the changes observed in social life. In this sense, social perspective towards the development of tourism can possibly reflect the existing culture. In other words, socio-culture is not only an interpretation tool of a community but it can also become the way of interpretation of the same community.

\section{Methodology}

Qualitative method has been used in the study and this method has made it possible to collect data realistically and without being manipulated (Yüksel and Yüksel, 2004). Hence, data has been collected from 187 people selected through convenience sampling method in central Adryaman. An open-ended question form has been used as data collection tool. Open-ended question form has provided advantage in collecting more detailed data related to the subject of the study and reaching a greater number of people. Asking too many questions in interviews makes the participants get bored. Therefore, participants have been posed with three questions only, all of which cover the purpose of the study (Kozak, 2015). These questions were: The "socio-cultural"; "socioeconomic" and "geographical" barriers preventing tourism development. Demographic data were the first to be reviewed during the analysis process. The second stage consisted of categorizing the responses as per the number of recurring responses (Yıldırım and Şimşek, 2011). Then descriptive analysis method has been used in the final stage to categorize user comments under certain themes and turned into statements by keeping loyal to the original (Braun and Clarke, 2006).

\section{Findings}

Data acquired in the study have been categorized into three groups. The first group includes demographic data; second group includes data acquired through content analysis; while the third group includes data acquired through descriptive analysis.

\section{First Group Data}

As indicated by demographic data (see, Table 1), male and married participants constitute the majority. In terms of employment status, public workers are in first place. Furthermore, it is noteworthy that a great majority of the participants are native. Age groups had similar distributions. In addition, individuals with a bachelor's degree ranked first in the education category, while the number of people in age and income variables were similar. 


\section{Jomat}

Table 1. Demographic Data

\begin{tabular}{|c|c|c|c|c|c|}
\hline Age & $\mathrm{N}$ & $\%$ & Gender & $\mathrm{N}$ & $\%$ \\
\hline $18-25$ & 35 & 18.7 & Female & 83 & 44.4 \\
\hline $26-35$ & 53 & 28.3 & Male & 104 & 55.6 \\
\hline $36-45$ & 44 & 23.5 & \multicolumn{3}{|l|}{ Income } \\
\hline$\geq 46$ & 55 & 29.5 & $\leq 237 \$$ & 27 & 14.4 \\
\hline Marital status & & & $238 \$-385 \$$ & 74 & 39.5 \\
\hline Married & 113 & 61.4 & $386 \$-533 \$$ & 29 & 15.7 \\
\hline Single & 74 & 38.6 & $534 \$-681 \$$ & 24 & 12.8 \\
\hline Profession & & & $\geq 682 \$$ & 33 & 17.6 \\
\hline Unemployed & 42 & 22.4 & \multicolumn{3}{|l|}{ Education } \\
\hline Private sector & 61 & 32.6 & Primary education & 24 & 12.8 \\
\hline Public sector & 84 & 45.0 & Secondary education & 29 & 15.5 \\
\hline Birthplace & & & Associate degree & 30 & 16.1 \\
\hline Adiyaman & 135 & 72.1 & Bachelor's degree & 83 & 44.4 \\
\hline Other & 52 & 27.9 & Postgraduate & 21 & 11.2 \\
\hline Total & 187 & 100 & Total & 187 & 100 \\
\hline
\end{tabular}

\section{Second Group Data}

The first question posed to participants was the socio-cultural barriers preventing development in tourism. Their responses and percentage distributions are given in Table 2.

Table 2. Socio-Cultural Barriers

\begin{tabular}{|l|l|l|}
\hline Theme & $\mathbf{N}$ & $\mathbf{\%}$ \\
\hline Style of operation of local authorities & 139 & 26.5 \\
\hline lack of advertisement & 121 & 23.1 \\
\hline $\begin{array}{l}\text { Lack of development consciousness among } \\
\text { community }\end{array}$ & 94 & 17.9 \\
\hline Political and bureaucratic problems & 63 & 12.0 \\
\hline Dereliction & 35 & 6.7 \\
\hline Lack of tourism consciousness among community & 34 & 6.5 \\
\hline Natural and cultural environmental destruction & 28 & 5.3 \\
\hline Negative perception towards Adryaman & 9 & 2.0 \\
\hline Total & $\mathbf{5 2 3}$ & $\mathbf{1 0 0}$ \\
\hline Source: & &
\end{tabular}

In terms of socio-cultural barriers preventing tourism development, the main issues pointed out by participants were the style of operation of local authorities, lack of advertisement and a lack of development awareness among community.

In the second part, participants were asked about the socio-economic barriers preventing tourism development. Their responses and percentage distributions are given in Table 3.

Table 3. Socio-Economic Barriers

\begin{tabular}{|l|l|l|}
\hline Theme & N & \% \\
\hline Lack of investment & 98 & 55.5 \\
\hline Insufficient quality in touristic infrastructure and service & 25 & 14.2 \\
\hline Local economy & 22 & 12.4 \\
\hline Lack of tourism-related investment & 18 & 10.2 \\
\hline Unplanned physical environment & 16 & 7.7 \\
\hline Total & $\mathbf{1 7 6}$ & $\mathbf{1 0 0}$ \\
\hline Source:
\end{tabular}

In terms of socio-economic barriers, one of the important issues pointed out was the lack of tourism-related investment, not only in Adiyaman but as a general issue in tourism. Furthermore, insufficient quality in touristic infrastructure and service is being perceived as another barriers.
Participants have been finally asked about the geographical barriers preventing tourism development. Their responses and percentage distributions are given in Table 4.

Table 4. Geographical Barriers

\begin{tabular}{|l|l|l}
\hline Theme & $\mathbf{N}$ & $\mathbf{\%}$ \\
\hline Transportation problem & 34 & 55.6 \\
\hline Geographical location & 13 & 21.2 \\
\hline Terror perception & 8 & 13.1 \\
\hline Proximity to provinces with touristic varieties & 6 & 10.1 \\
\hline Total & $\mathbf{6 1}$ & $\mathbf{1 0 0}$ \\
\hline Source:
\end{tabular}

According to Table 4, the issue of transport has been perceived as the most important geographical problem. In addition, the location of the problem, perception of terror and proximity to provinces with touristic varieties have been listed as other barriers.

\section{Third Group Data}

Issues related to the activities of local authorities have been listed as an important barrier by the participants, who also believe that lack of regional investments creates a dilemma in tourism development. Local authorities bear important responsibilities during the regional development process (Cavaye and Cavaye, 2000), therefore it is important that they prioritize all types of investments related to tourism (Tosun, Okumuş and Fyall, 2008). Related to this point, the following expression has been stated by one of the participants:

\section{"...Local authorities do not perform strong and credible projects."}

Furthermore, another participant made an assessment of the local authority in terms of investments and stated:

“...Unfortunately, public and private sector instruments are not being used sufficiently to make tourism better."

Similarly, another participant stated: 
"Local administrators should pay attention to tourism as much as other areas."

Failing to make sufficient amount of advertisement, issue of transportation and lack of development -awareness among the community have been listed by the participants as the noteworthy barriers. A study by Yllmaz and Çalışkan (2015) listed transport, lack of marketing and lack of local interest towards tourism as structural issues in tourism development. Participants have stated the following on this subject:

\section{"Transport is difficult in Adlyaman to go sightseeing..." \\ "The connection to neighbouring provinces is not sufficient." \\ “...No large-scale festivals are being organized... Adlyaman should not be a forgotten city." \\ "Most of the locals spent their leisure time by doing traditional activities, such as visiting their families, and they do not have any intention to seek any new social or cultural activity... Indeed, people of Adyaman are indifferent towards tourism being developed"}

\section{Conclusion and Discussion}

Despite a potential to become a tourism destination, Adryaman cannot fulfil this potential and it is understood that this issue has a social aspect (Yılmaz and Çalışkan, 2015). As such, the above listed barriers have been analyzed from a social perspective thanks to this foresight.

Analysis of the demographic structure of participants indicate two main points. The first one is the young-population potential and the second is the fact that majority of the participants are from Adiyaman. It must be emphasized that the acquired results tally with the actual demographic structure of the province (see TUIK, 2020). On the other hand, it is believed that these two elements are offering great opportunities for Adıyaman. As such, it can be said that both of these two elements are important factors to help achieve dynamism (Paksoy and Aydoğu, 2010) and the sense of ownership/belonging (Çalışkan, 2015).

According to data acquired from the study, issues such as bureaucracy, lack of investment, transport and social awareness are the main barriers preventing tourism from growing. Considering the relevant literature, it is indeed the bureaucratic dilemmas (Liu, 1994; Yüksel, Bramwell and Yüksel, 2005), insufficient investment level (Surugiu, 2012), transportation problems (Kantawateera, et. Al., 2015) and insufficient social awareness (Saarinen, 2010) are observed to be important obstacles. In fact, for the efforts aiming to develop tourism in a region to gain momentum (Singgalen, Sasongko and Wiloso, 2018) the foremost requirement is to have a fast-running bureaucratic process (Tosun, 2000). Furthermore, it is also essential to ensure that the efforts in question are society-oriented (Meppem and Gill, 1998) and socio-cultural values are taken into account (Neto, 2003). However, the perception of local communities towards tourism are influenced by ethnicity, beliefs and existing social perceptions (Liu, 2006). At this point, having administrators who are familiar with social structure and analysing tendencies would be a strategic approach (Macnaghten and Jacobs, 1997).

Another matter revealed by the study data is geography. Participants believe accessibility is a geographical dilemma. However, it is also true that an allegedly disadvantageous geographic location of a region could be turned into advantage. For instance, even though Adryaman is ranked among developed touristic provinces, it can be turned into an area of social interaction among the other regions through an effective tourism planning (Haley, Snaith and Miller, 2005). At this point, the importance of advertising and marketing is once again revealed and it should not be forgotten that geographical uniqueness is an element of attraction (Higgins-Desbiolles, 2006).

In conclusion, Adıyaman is located in a unique and rich geography and it should be able to use its social dynamics. In this sense, it is believed that increasing tourism-related social awareness, availing of the potential of young population and concentrating on cultural elements are important factors (Çalışkan and Dedeoğlu, 2018).

The findings of this current study should surely be assessed specifically for Adiyaman. With regards to future studies, comparison of different regions with similar social structures can be recommended.

\section{References}

Ahmad, A. (2013). The constraints of tourism development for a cultural heritage destination: the case of Kampong Ayer (Water Village) in Brunei Darussalam. Tourism Management Perspectives, 8: 106-113.

Akama, J. S. and Kieti, D. (2007). Tourism and socioeconomic development in developing countries: A case study of Mombasa Resort in Kenya. Journal of sustainable tourism, 15(6), 735-748.

Akdağ, G. and Öter, Z. (2011). Assessment of world tourism from a geographical perspective and a comparative view of leading destinations in the 
market. Procedia-Social and Behavioral Sciences, 19, 216-224.

Akinboade, O. A. and Braimoh, L. A. (2010). International tourism and economic development in South Africa: A Granger causality test. International Journal of Tourism Research, 12(2), 149-163.

Andereck, K. L. and Vogt, C. A. (2000). The relationship between residents' attitudes toward tourism and tourism development options. Journal of Travel research, 39(1), 27-36.

Archer, B., Cooper, C. and Ruhanen, L. (2005). The positive and negative impacts of tourism. In W. F. Theobald (Ed.), Global tourism (3rd ed., p. 561). Burlington: Elsevier Butterworth-Heinemann.

Aref, F. (2010). Barriers to Community Capacity Building for Tourism Development in Communities in Shiraz. Journal of Sustainable Tourism, 19(3), 347-359.

Avcıkurt, C. (2009). Turizm Sosyolojisi, Genel ve Yapısal Yaklaşım. Ankara: Detay Yayıncılık.

Bjeljac, Ž. and Ćurčić, N. (2006). Tourism in the Serbian, Romanian and Hungarian borderline area as part of cross-border cooperation. Geographica Pannonica, (10), 73-77.

Braun, V. and Clarke, V. (2006). Using thematic analysis in psychology. Qualitative Research in Psychology, 3(2), 77-101.

Budeanu, A. (2005), Impacts and Responsibilities for Sustainable Tourism: A Tour Operator's Perspective. Journal of Cleaner Production (13), 89-97.

Cavaye, J. M. and Cavaye, J. (2000). The Role of Government In Community Capacity Building. Brisbane: Department of Primary Industries.

Chandralal, K.P.L. (2010). Impacts of tourism and community attitude towards tourism: A case study in Sri Lanka. South Asian Journal of Tourism and Heritage, 3(2), 41-49.

Choi, H.C. and Sirakaya, E. (2005). Measuring residents' attitude toward sustainable tourism: Development of sustainable tourism attitude scale. Journal of Travel Research, 43(4), 380-394.

Çalışkan, C. (2015). Turizm Potansiyeli Olan Bölgelerin Kalkınma Sürecinde Toplumsal Kapasiteyi Güçlendirme Stratejileri: Adıyaman Örneği, Nevşehir Hacı Bektaş Veli Üniversitesi Sosyal Bilimler Enstitüsü, Yayınlanmamış Doktora Tezi, Ocak 2015, Nevşehir.

Çalışkan, C. and Dedeoğlu, B.B. (2018): Human geography and branding in small destinations: a case study of Adryaman, Asia Pacific Journal of Tourism Research, 10.1080/10941665.2018.1544157
Dinu, A. M. (2018). The importance of transportation to tourism development. Academic Journal of Economic Studies, 4(4), 183-187.

Doğan, Z. (2004). Turizmin Sosyo-Kültürel Temelleri. Ankara: Detay Yayıncılık.

Dowling, R. (1993). An environmentally-based planning model for regional tourism development. Journal of Sustainable Tourism, 1(1), 17-37.

Eshliki, S. A. and Kaboudi, M. (2012). Community perception of tourism impacts and their participation in tourism planning: a case study of Ramsar, Iran. Procedia-Social and Behavioral Sciences, 36, 333-341.

Farole, T., Rodríguez-Pose, A. and Storper, M. (2011). Human geography and the institutions that underlie economic growth. Progress in Human Geography, 35(1), 58-80.

Franklin, A. and Crang, M. (2001). The trouble with tourism and travel theory. Tourist Studies, 1(1), 5-22.

Furmolly, A. W., \& Kirkulak Uludağ, B. (2018). The impact of tourism on Turkish economy (19632015). Journal of Multidisciplinary Academic Tourism, 3(1), 11-22. https://doi.org/10.31822/jomat.364321

García, F. A., Vázquez, A. B. and Macías, R. C. (2015). Resident's attitudes towards the impacts of tourism. Tourism Management Perspectives, 13, 33-40.

Ghanian, M., Ghoochani, O. M. and Crotts, J. C. (2014). An application of European Performance Satisfaction Index towards rural tourism: The case of western Iran. Tourism Management Perspectives, 11, 77-82.

Giddens, A. (2013). Sosyoloji (Çev. Cemal Güzel). İstanbul: Kırmızı Yayınları.

Grandpré, F. D. and Py, B. (2007). Tourism and Territories. Tourism and Territories, Loisir et Société / Society and Leisure, 30(1), 17-21.

Gursoy, D. and Rutherford, D. G. (2004). Host attitudes toward tourism: An improved structural model. Annals of tourism Research, 31(3), 495-516.

Gursoy, D., Jurowski, C. and Uysal, M. (2002). Resident attitudes: A structural modeling approach. Annals of tourism research, 29(1), 79-105.

Haley, J. A., Snaith, T. and Miller, G. (2005). The social impacts of tourism a case study of Bath, UK. Annals of Tourism Research, 32(3), 647-668.

Hancock, T. (2001). People, partnerships and human progress: building community capital. Health promotion international, 16(3), 275-280.

Harrill, R. (2004). Residents' attitudes toward tourism development: A literature review with 
implications for tourism planning. Journal of Planning Literature, 18(3), 251-266.

Henderson, J. C. (2006). Tourism in Dubai: Overcoming barriers to destination development. International Journal of Tourism Research, 8(2), 87-99.

Higgins-Desbiolles, F. (2006). More than an industry, the forgotten power of tourism as a social force. Tourism Management 27(6), 1192-1208.

Homsud, N. and Promsaard, S. (2015). The effects of residents' image and perceived tourism impact to residence satisfaction and support: A case study of hua-hin prachubkirikhan. In The 2015 WEI International Academic Conference Proceedings (pp. 190-199).

Jakobsen, O. (2017). Transformative Ecological Economics: Process Philosophy, Ideology and Utopia. Routledge.

James, V.U. (Ed.). (1998). Capacity building in developing countries: Human and environmental dimensions. Greenwood Publishing Group.

Jansen, L.(2003). The challenge of sustainable development. Journal of Cleaner Production, 11(3), 231-245.

Jiang, W. Q., Li, J. S., Chen, G. Q., Yang, Q., Alsaedi, A., Ahmad, B. and Hayat, T. (2016). Mercury emissions embodied in Beijing economy. Journal of Cleaner Production, 129, 134-142.

Joo, D., Woosnam, K. M., Shafer, C. S., Scott, D. and An, S. (2017). Considering Tobler's first law of geography in a tourism context. Tourism Management, 62, 350-359.

Jurowski, C., Uysal, M. and Williams, D. R. (1997). A Theoretical Analysis of Host Community Resident Reactions to Tourism. Journal of Travel Research, $36(2), 3-11$.

Kantawateera, K., Naipinit, A., Sakolnakorn, T. P. N., \& Kroeksakul, P. (2015). Tourist transportation problems and guidelines for developing the tourism industry in Khon Kaen, Thailand. Asian Social Science, 11(12), 89-95.

Karakuş, Y. (2019). Identifying the best alternative tourism product for a destination: the case of Cappadocia. Revista Anais Brasileiros de Estudos Turísticos - ABET, 9(1, 2 e 3).

Kim, H. J., Chen, M. H. and Jang, S. (2006). Tourism expansion and economic development: the case of Taiwan. Tourism Management, 27(5), 925-933.

Kim, K., Uysal, M. and Sirgy, M.J. (2013). How does tourism in a community impact the quality of life of community residents?. Tourism Management $36,527-540$.

Knox, P. and Pinch, S. (2014). Urban social geography: an introduction. Routledge.
Kozak, M. (2015). Bilimsel Araştırma: Tasarım: Yazım ve Yayım Teknikleri. (2. Baskı). Ankara: Detay Yayıncılık.

Larsen, J. (2008). De-exoticizing tourist travel: everyday life and sociality on the move. Leisure Studies, $27(1), 21-34$

Lee, C. C. and Chang, C. P. (2008). Tourism Development and Economic Growth: A Closer Look At Panels. Tourism Management, 29(1), 180-192.

Liang, J. and Chan, C. S. (2018). Local cultural vicissitudes in regional tourism development: A case of Zhuhai. Tourism management perspectives, 25, 80-92.

Lee, T. H. (2013). Influence analysis of community resident support for sustainable tourism development. Tourism management, 34, 37-46.

Lin, D., Li, W. and Hong, X. (2012). The Research on the Soft Power of City Culture. Studies in Sociology of Science, 3(2), 49 .

Liu, Z.H. (1994). Tourism Development-A System Analysis. In A.V. Seaton (Ed.), Tourism: The State of Art (pp. 20-30). Chichester: John Wiley \& Sons.

Liu, A. (2006). Tourism In Rural Areas: Kedah, Malaysia. Tourism Management, 27(5), 878-889.

Macbeth, J., Carson, D. and Northcote, J. (2004). Social capital, tourism and regional development: SPCC as a basis for innovation and sustainability. Current Issues in Tourism, 76), 502-522.

Macnaghten, P. and Jacobs, M. (1997). Public Identification with Sustainable Development: Investigating Cultural Barriers to Participation. Global Environmental Change, 7(1), 5-24.

Matthews, G. H. and Richter, K. L. (1991). Political Science and Tourism. Annals of Tourism Research, 18(1), 120-135.

McCool, S. F. and Martin, S. R. (1994). Community attachment and attitudes toward tourism development. Journal of Travel research, 32(3), 29-34.

Meppem, T. and Gill, R. (1998). Planning for Sustainability As A Learning Concept. Ecological Economics 26(2): 121-137.

Morton, W.L. (2003). Small town services and facilities: The influence of social networks and civic structure on perceptions of quality. City \& Community, 2(2), 102-120.

Mutsikiwa, M. and Basera, C. H. (2012). The influence of socio-cultural variables on consumers' perception of halal food products: A case of masvingo urban, zimbabwe. International Journal of Business and Management, 7(20), 112 
Neto, F. (2003). A new approach to sustainable tourism development: moving beyond environmental protection. N.Resources Forum, 27(3), 212-222.

Paksoy, S. and Aydoğdu, M.H. (2010). Bölgesel kalkınmada girişimciliğin geliştirilmesi: GapGidem örnekleri. Girişimcilik ve Kalkınma, 5(1), $113-134$

Perdue, R. R., Long, P. T. and Allen, L. (1990). Resident support for tourism development. Annals of Tourism Research, 174), 586-599.

Reisinger, Y. and Turner, L. (2003). Cross-cultural behaviour in tourism. Routledge.

Rentfrow, P. J., Jokela, M. and Lamb, M. E. (2015). Regional personality differences in Great Britain. Plos One, 10(3), 1-20.

Rızaoğlu, B. (2003). Turizm Davranışı. Ankara: Detay Yayıncilık.

Robinson, M. (1999). Collaboration and cultural consent: refocusing sustainable tourism. Journal of Sustainable Tourism, 7(3-4), 379-397.

Romão, J., Guerreiro, J. and Rodrigues, P. (2013). Regional tourism development: culture, nature, life cycle and attractiveness. Current Issues in Tourism, 16(6), 517-534.

Sanmargaraja, S. and Wee, S.T. (2013). Constraints of alternative tourism in Malaysia. International Journal of Advances in Management, Technology \& Engineering Sciences, 2(12), 9-12.

Saarinen, J. (2010). Local tourism awareness: community views in Katutura and King Nehale conservancy, Namibia. Development Southern Africa, 27(5), 713-724.

Singgalen, Y. A., Sasongko, G. and Wiloso, P. G. (2018). Tourism destination in remote area: problems and challenges of tourism development in North Halmahera as remote and border areas of Indonesia-Philippines. Journal of Indonesian Tourism and Development Studies, 6(3), 175-186.

Stoltman, J. P. (1997). The International charter on geographical education: Setting the curriculum standard. Journal of Geography, 96(1), 32-32.

Stylidis, D., Biran, A., Sit, J. and Szivas, E. M. (2014). Residents' support for tourism development: The role of residents' place image and perceived tourism impacts. Tourism Management, 45, 260274.

Surugiu, C., Surugiu, M. R., Dinca, A. I. and Frent, C. (2012). Labour productivity and investments as determinants of wages: a pool data analysis of the Romanian hotel and restaurant sector. Tourism economics, 18(1), 219-242.

Telfer, D. J. (2002) Tourism and regional development issues, in: Sharpley, R. \& D.J. Telfer (Eds) Tourism and Development: Concepts and Issues, pp. 112-148. Clevedon, UK: ChannelView Publications.

Tosun, C. (2000). Limits to community participation in the Tourism Development Process in Developing Countries. Tourism Management, 21(6), 613-633.

Tosun, C., Okumus, F. and Fyall, A. (2008). Marketing philosophies: evidence from Turkey. Annals of Tourism Research, 35(1), 127-147.

Tucker, H. and Boonabaana, B. (2012). A critical analysis of tourism, gender and poverty reduction. Journal of Sustainable Tourism, 20(3), 437-455.

TUIK (2020). Adrese Dayalı Nüfus Kayıt Sistemi, www.tuik.gov.tr/PreTablo.do?alt_id=1059 (last accessed: 10.05.2020).

Urry, J. (2015). Mekânları Tüketmek (Çev. Rahmi G. Öğgül). İstanbul: Ayrıntı Yayınları.

Usta, Ö. (2009). Turizm Genel ve Yapısal Yaklaşım. Ankara: Detay Yayıncılık.

Waligo, V. M., Clarke, J. and Hawkins, R. (2013). Implementing Sustainable Tourism: A multiStakeholder Involvement Management Framework. Tourism Management 36, 342-353.

Walmsley J. (Ed.) (2002). Principles and Types of Advocacy in Advocacy and Learning Disability. London: Jessica Kingsley Publishers.

Wu, S. T. and Chen, Y. S. (2015). The social, economic, and environmental impacts of casino gambling on the residents of Macau and Singapore. Tourism Management, 48, 285-298.

Yıldırım, A. and Şimşek, H. (2011). Sosyal Bilimlerde Nitel Araştırma Yöntemleri. Ankara: Seçkin Yayıncilık.

Yılmaz, İ. and Çalışkan, C. (2015). Turizm potansiyeli olan bölgelerde toplumsal kapasite algisl: Adıyaman Örneği. Journal of Yasar University, 10(39), $6555-6611$.

Yoon, Y., Gursoy, D. and Chen, J. S. (2001). Validating a tourism development theory with structural equation modeling. Tourism Management, 22(4), 363-372.

Yüksel, A. and Yüksel, F. (2004). Turizmde Bilimsel Araştırma Yöntemleri. Ankara: Turhan Kitabevi.

Yüksel, F., Bramwell, B. and Yüksel, A. (2005). Centralized and decentralized tourism governance in Turkey. Annals of tourism research, 32(4), 859-886. 